\title{
Reactivity and crystal structures of the first dithiocarbamate chromium(0) and dithiophosphate tungsten(0) complexes: crystal structures of $\left[\mathrm{Et}_{4} \mathrm{~N}\right]\left[\mathrm{Cr}\left(\eta^{2}-\mathrm{S}_{2} \mathrm{CNC}_{5} \mathrm{H}_{10}\right)(\mathrm{CO})_{4}\right]$ and $\left[\mathrm{Et}_{4} \mathrm{~N}\right]\left[\mathrm{W}\left\{\eta^{2}-\right.\right.$ $\left.\mathrm{S}_{2} \mathrm{P}(\mathrm{OEt})_{2}(\mathrm{CO})_{4}\right]$
}

\author{
Kuang-Hway Yih $^{\mathrm{a}, *}$, Gene-Hsiang Lee ${ }^{\mathrm{b}}$, Shou-Ling Huang ${ }^{\mathrm{b}}$, Yu Wang ${ }^{\mathrm{c}}$ \\ ${ }^{a}$ Department of Applied Cosmetology, Hung Kuang Institute of Technology, 34 Chung Chi Road, Shalu, Taichung Hsien 433, Taiwan, ROC \\ ${ }^{\mathrm{b}}$ Instrumentation Center, College of Science, National Taiwan University, 106, Taiwan, ROC \\ ${ }^{\mathrm{c}}$ Department of Chemistry, National Taiwan University, 106, Taiwan, ROC
}

Received 23 July 2002; received in revised form 29 October 2002; accepted 29 October 2002

\begin{abstract}
The structures of first dithiocarbamate chromium(0) complex $\left[\mathrm{Et}_{4} \mathrm{~N}\right]\left[\mathrm{Cr}\left(\eta^{2}-\mathrm{S}_{2} \mathrm{CNC}_{5} \mathrm{H}_{10}\right)(\mathrm{CO})_{4}\right](\mathbf{1})$ and the diethyldithiophosphate tungsten $(0)$ complex $\left[\mathrm{Et}_{4} \mathrm{~N}\right]\left[\mathrm{W}\left\{\eta^{2}-\mathrm{S}_{2} \mathrm{P}(\mathrm{OEt})_{2}(\mathrm{CO})_{4}\right](2)\right.$ have been determined by X-ray diffraction analyses. Crystal data for 1: space group, $P 2_{1}$ with $a=10.240(2) \AA, b=12.705(4) \AA, c=9.888(2) \AA, \beta=117.26(2)^{\circ}, V=1143.6(4) \AA^{3}$, and $Z=2$. The structure was refined to $R=0.027$ and $R_{\mathrm{w}}=0.028$; Crystal data for 2: space group, $C 2 / c$ with $a=13.054$ (6) $\AA, b=16.220$ (4) $\AA, c=$ 11.417 (3) $\AA, \beta=93.73(3)^{\circ}, V=2412.3$ (14) $\AA^{3}$, and $Z=4$. The structure was refined to $R=0.026$ and $R_{\mathrm{w}}=0.019$. The geometry around the metal atom in the anion of these two complexes is a distorted octahedron. The dithiocarbamato and diethyldithiophosphato ligands, respectively, coordinate to the $\mathrm{Cr}$ and $\mathrm{W}$ metal center through the two sulfur atoms. The short $\mathrm{C}-\mathrm{N}$ bond length of $1.335(4) \AA$ in 1 indicates a considerable partial double bond character. The allyl dithiophosphate tungsten complex $\left[\mathrm{W}\left(\mathrm{CH} \mathrm{H}_{3} \mathrm{CN}\right)\left(\eta^{3}-\right.\right.$ $\left.\left.\mathrm{C}_{3} \mathrm{H}_{5}\right)(\mathrm{CO})_{2}\left\{\eta^{2}-\mathrm{S}_{2} \mathrm{P}(\mathrm{OEt})_{2}\right\}\right]$ (3) can be obtained from the reaction of $\left[\mathrm{W}\left(\mathrm{CH}_{3} \mathrm{CN}\right)_{2}\left(\eta^{3}-\mathrm{C}_{3} \mathrm{H}_{5}\right)(\mathrm{CO})_{2} \mathrm{Br}\right]$ and $(\mathrm{EtO})_{2} \mathrm{PS}_{2} \mathrm{NH}_{4}$ in $\mathrm{CH}_{3} \mathrm{CN}$ at room temperature but decomposed in the reaction of 2 with allyl bromide. Complex 3 reacted with dppe in $\mathrm{CH}_{2} \mathrm{Cl}_{2}$ at room temperature to give a mixture of complex $\left[\mathrm{W}\left(\eta^{3}-\mathrm{C}_{3} \mathrm{H}_{5}\right)(\mathrm{CO})_{2}\left\{\eta^{2}-\mathrm{S} \mathrm{S}_{2} \mathrm{P}(\mathrm{OEt})_{2}\right\}\right]_{2}(\mu-\mathrm{dppe})(\mathbf{4})$ and $\left[\mathrm{W}\left(\eta^{3}-\mathrm{C}_{3} \mathrm{H}_{5}\right)(\mathrm{CO})_{2}\left\{\eta^{2}-\right.\right.$ $\mathrm{S}_{2} \mathrm{P}(\mathrm{OEt})_{2}\left(\eta^{1}\right.$-dppe $\left.)\right](5)$.
\end{abstract}

(C) 2002 Elsevier Science B.V. All rights reserved.

Keywords: Chromium; Tungsten; Dithiocarbamato ligand; Diethyldithiophosphato ligand; Crystal structures

\section{Introduction}

Although the chemistry of dithio-metal complexes have been widely studied in bonding mode [1], cubanelike cluster [2], bisalkyne complexes [3], catalyst [4], and redox-active enzymes [5], only very few dithio$\mathrm{M}(\mathrm{VIB})(0)$ derivatives have been reported so far.

A recent article reported the synthesis of dithiocarbamate metal complexes of the type $\left[\mathrm{Et}_{4} \mathrm{~N}\right]\left[\mathrm{M}\left(\eta^{2}-\right.\right.$ $\left.\left.\mathrm{S}_{2} \mathrm{CNEt}_{2}\right)(\mathrm{CO})_{4}\right] \quad(\mathrm{M}=\mathrm{Mo}, \mathrm{W})$ [6] from the direct reaction of $\mathrm{M}(\mathrm{CO})_{6}$ with $\mathrm{NaS}_{2} \mathrm{CNEt}_{2}$ in the presence of $\mathrm{Et}_{4} \mathrm{NCl}$ in $\mathrm{MeCN}$ but the analogue chromium

* Corresponding author. Fax: +88-646-321-046

E-mail address: khyih@sunrise.hkc.edu.tw (K.-H. Yih). complex could not be synthesized by this method. The late transition-metal dithiophosphato complexes are most common, while the early transition metals are quite rare. For the VIB group, complexes involving dithiophosphato ligands have been reported in high oxidation-state [7]. The low oxidation-state of the organometallic dithiophosphate molybdenum complexes have been studied in $\left[\mathrm{Et}_{4} \mathrm{~N}\right]\left[\mathrm{Mo}\left\{\eta^{2}-\right.\right.$ $\left.\left.\mathrm{S}_{2} \mathrm{P}(\mathrm{OEt})_{2}(\mathrm{CO})_{4}\right]\right][8],\left[\mathrm{CpMo}\left\{\eta^{2}-\mathrm{S}_{2} \mathrm{P}(\mathrm{OR})_{2}\right\}_{2}(\mathrm{NO})\right][9]$, $\left[\mathrm{Mo}\left\{\eta^{2}-\mathrm{S} 2 \mathrm{P}(\mathrm{OEt})_{2}\right\}(\mathrm{CO})_{2}\left(\mathrm{~S}_{2} \mathrm{CPCy}_{3}\right)\left(\mathrm{SnPhCl}_{2}\right)\right][10]$ and $\left[\mathrm{Mo}\left(\eta^{3}-\mathrm{C}_{3} \mathrm{H}_{5}\right)(\mathrm{CO})_{2}\left\{\eta^{2}-\mathrm{S}{ }_{2} \mathrm{P}(\mathrm{OEt})_{2}\right\}\right]_{2}\left(\mu-\mathrm{NH}_{2} \mathrm{NH}_{2}\right)[11]$. Some reports described the $[\mathrm{Cat}]\left[\mathrm{M}(\mathrm{CO})_{4} \mathrm{~L}-\mathrm{L}\right](\mathrm{Cat}=$ $\mathrm{Na}, \mathrm{K}, \mathrm{NH}_{4} ; \mathrm{L}-\mathrm{L}=$ dithiocarbamato, xanthato, dithiophosphato) type complexes and these complexes were very unstable and non-isolable [12]. Notably, till now, 
these complexes are rarely subjected to crystallographic study [13] and there is no example involving the dithiocarbamate $\operatorname{Cr}(0)$ or dithiophosphate $\mathrm{W}(0)$ complex.

Our interest in the sulfur containing ligands [14] and the paucity of $\mathrm{Cr}(0)$ and $\mathrm{W}(0)$ complexes involving $\mathrm{R}_{2} \mathrm{NCS}_{2}^{-}$or (EtO) $)_{2} \mathrm{PS}_{2}^{-}$ligands prompted us to explore the possibility of obtaining the crystal structures of these complexes.

\section{Results and discussion}

\subsection{X-ray structures determination of $\left[E t_{4} N\right]\left[C r\left(\eta^{2}\right.\right.$ - $\left.\left.\mathrm{S}_{2} \mathrm{CNC}_{5} \mathrm{H}_{10}\right)(\mathrm{CO})_{4}\right](\mathrm{I})$ and $\left[E t_{4} \mathrm{~N}\right]\left[\mathrm{W}\left\{\eta^{2}-\right.\right.$ $\left.\left.\mathrm{S}_{2} \mathrm{P}(\mathrm{OEt})_{2}\right\}(\mathrm{CO})_{4}\right](2)$}

We have reported the reaction of (pip) ${ }_{2} \mathrm{Cr}(\mathrm{CO})_{4}$ (pip: piperidine, $\mathrm{C}_{5} \mathrm{H}_{10} \mathrm{NH}$ ) complexes with $n$-BuLi and $\mathrm{CS}_{2}$ in the presence of $\mathrm{Et}_{4} \mathrm{NBr}$ to give complex $\left[\mathrm{Et}_{4} \mathrm{~N}\right]\left[\mathrm{Cr}\left(\eta^{2}-\right.\right.$ $\left.\left.\mathrm{S}_{2} \mathrm{CNC}_{5} \mathrm{H}_{10}\right)(\mathrm{CO})_{4}\right]$ (1) [15] and the nucleophilic substitution method in the reaction of $(\mathrm{EtO})_{2} \mathrm{PS}_{2} \mathrm{NH}_{4}$ with (pip) ${ }_{2} \mathrm{~W}(\mathrm{CO})_{4}$ in refluxing $\mathrm{CH}_{3} \mathrm{CN}$ which leads to the formation of the diethyldithiophosphate complex $\left[\mathrm{Et}_{4} \mathrm{~N}\right]\left[\mathrm{W}\left\{\eta^{2}-\mathrm{S}_{2} \mathrm{P}(\mathrm{OEt})_{2}\right\}(\mathrm{CO})_{4}\right](2)$ [8] in the presence of $\mathrm{Et}_{4} \mathrm{NBr}$ (Scheme 1).
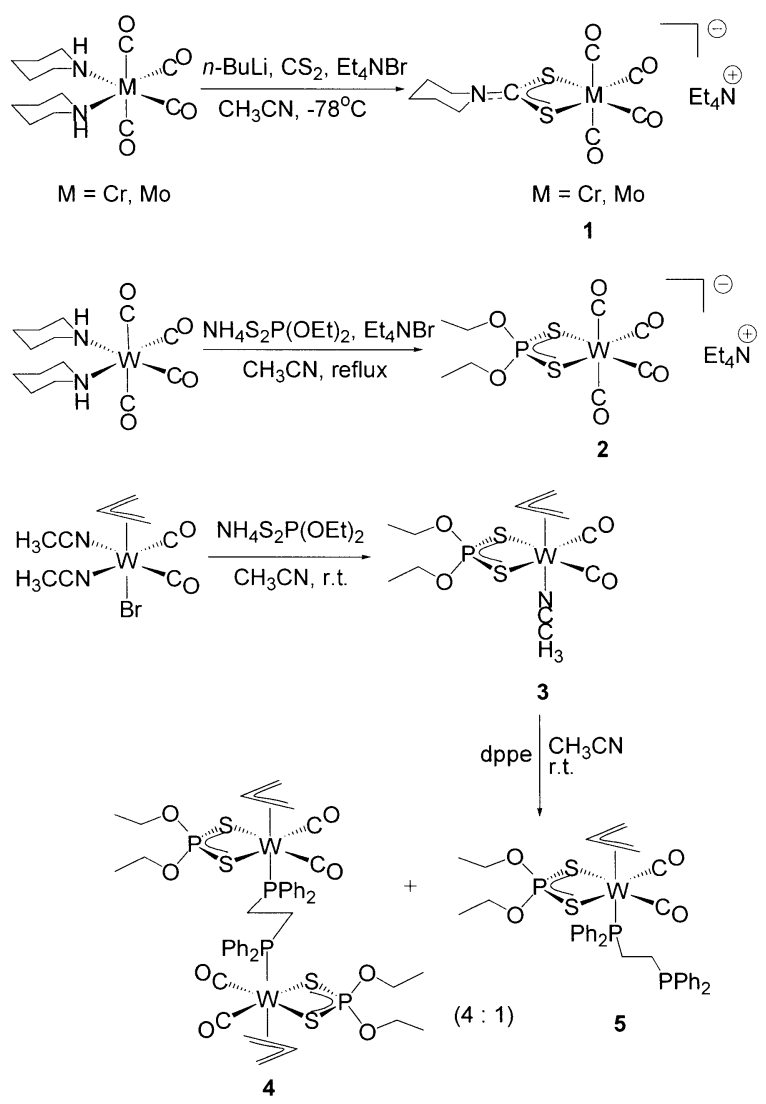

Scheme 1.

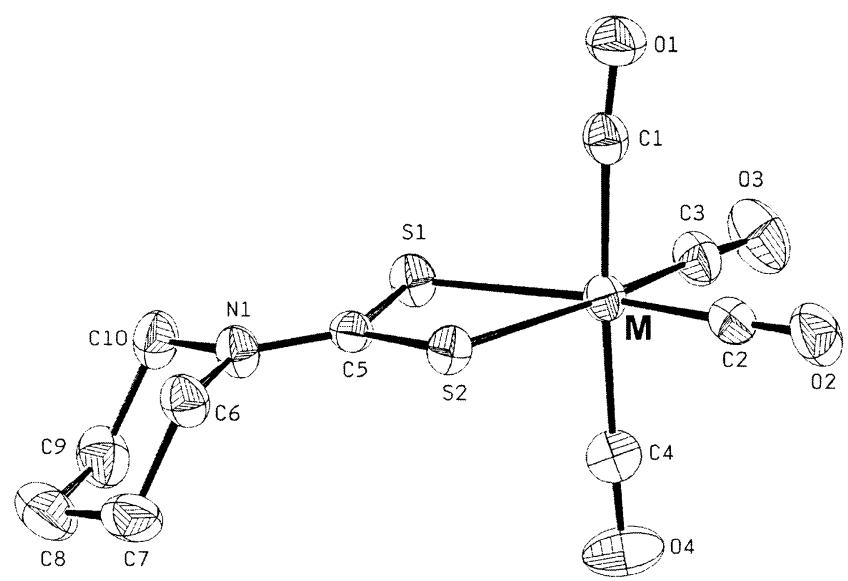

Fig. 1. An ORTEP drawing with $30 \%$ thermal ellipsoids and atomnumbering scheme for the anionic complex $\left[\mathrm{Et}_{4} \mathrm{~N}\right]\left[\mathrm{M}\left(\eta^{2}-\right.\right.$ $\left.\left.\mathrm{S}_{2} \mathrm{CNC}_{5} \mathrm{H}_{10}\right)(\mathrm{CO})_{4}\right](\mathrm{M}=\mathrm{Cr}, \mathbf{1} ; \mathrm{M}=\mathrm{Mo})$.

The ORTEP plots of the anion moiety of $\mathbf{1}$ and $\mathbf{2}$ are shown in Figs. 1 and 2, respectively. The cell constants and other pertinent data are shown in Table 1. Tables 2 and 4 contain selected bond distances and angles of $\mathbf{1}$ and 2, respectively. As shown in the ORTEP plots, the geometry around the metal atom in the anion of the two compounds are both a distorted octahedron with a small SCrS angle of $70.84(5)^{\circ}$ and a small dihedral angle of $1.01^{\circ}$ between the plane $\operatorname{CrS}(1) \mathrm{S}(2)$ and the plane $\mathrm{CrC}(2) \mathrm{C}(3)$ in $\mathbf{1}$ and a small SWS(a) angle of 76.07(7) ${ }^{\circ}$ and a small dihedral angle of $0.47^{\circ}$ between the plane WSS(a) and the plane $\mathrm{WC}(4) \mathrm{C}(4 \mathrm{a})$ in 2 . The dihedral angles in 1 between the plane $\mathrm{CrC}(1) \mathrm{C}(4)$ and the plane $\mathrm{CrS}(1) \mathrm{S}(2)$ and between the plane $\mathrm{CrC}(1) \mathrm{C}(4)$ and the plane $\mathrm{CrC}(2) \mathrm{C}(3)$ are 89.87 and $89.65^{\circ}$, respectively, and between the plane $\mathrm{WC}(3) \mathrm{C}(3 \mathrm{a})$ and the plane WSS(a) and between the plane $\mathrm{WC}(3) \mathrm{C}(3 \mathrm{a})$ and the plane $\mathrm{WC}(4) \mathrm{C}(4 \mathrm{a})$ are 90.25 and $89.78^{\circ}$ in 2 , respectively. The anion structure of $\mathbf{1}$ possesses a pseudo- $C_{2}$ axis through $\mathrm{Cr}, \mathrm{C}(5)$ and $\mathrm{N}(1)$ atoms and thus acquires a

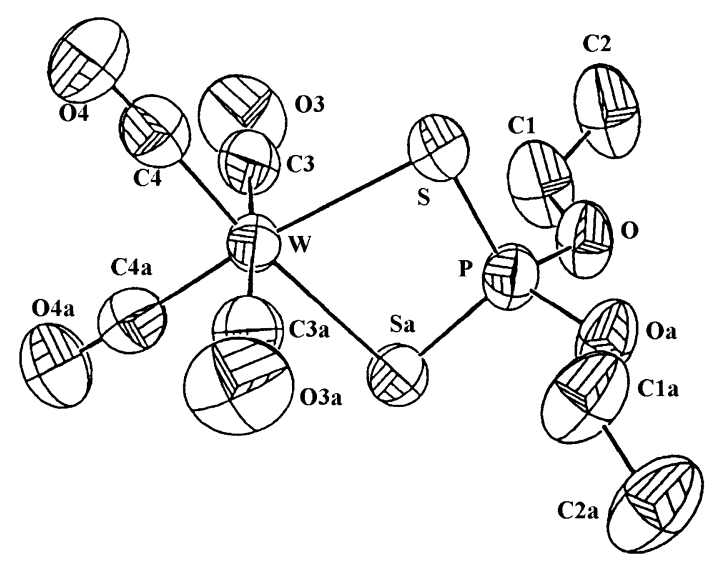

Fig. 2. An ORTEP drawing with $30 \%$ thermal ellipsoids and atomnumbering scheme for the anionic complex $\left[\mathrm{Et}_{4} \mathrm{~N}\right]\left[\mathrm{W}\left\{\eta^{2}-\right.\right.$ $\left.\left.\mathrm{S}_{2} \mathrm{P}(\mathrm{OEt})_{2}\right\}(\mathrm{CO})_{4}\right](2)$. 
Table 1

Crystal data and refinement details for complexes $\left[\mathrm{Et}_{4} \mathrm{~N}\right]\left[\mathrm{Cr}\left(\eta^{2}-\right.\right.$ $\left.\left.\mathrm{S}_{2} \mathrm{CNC}_{5} \mathrm{H}_{10}\right)(\mathrm{CO})_{4}\right](\mathbf{1})$ and $\left[\mathrm{Et}_{4} \mathrm{~N}\right]\left[\mathrm{W}\left\{\eta^{2}-\mathrm{S}_{2} \mathrm{P}(\mathrm{OEt})_{2}\right\}(\mathrm{CO})_{4}\right](\mathbf{2})$

\begin{tabular}{|c|c|c|}
\hline & 1 & 2 \\
\hline Formula & $\mathrm{C}_{18} \mathrm{H}_{30} \mathrm{~N}_{2} \mathrm{O}_{4} \mathrm{~S}_{2} \mathrm{Cr}$ & $\mathrm{C}_{16} \mathrm{H}_{30} \mathrm{NO}_{6} \mathrm{PS}_{2} \mathrm{~W}$ \\
\hline Formula weight & 454.56 & 611.35 \\
\hline Crystal system & Monoclinic & Monoclinic \\
\hline Crystal size (mm) & $0.50 \times 0.50 \times 0.40$ & $0.35 \times 0.40 \times 0.40$ \\
\hline Space group & $P 2_{1}$ & $C 2 / c$ \\
\hline$a(\AA)$ & $10.240(2)$ & $13.054(3)$ \\
\hline$b(\AA)$ & $12.705(4)$ & $16.220(3)$ \\
\hline$c(\AA)$ & $9.888(2)$ & $11.416(2)$ \\
\hline$\beta\left({ }^{\circ}\right)$ & $117.260(15)$ & $93.73(2)$ \\
\hline$V\left(\AA^{3}\right)$ & $1143.6(4)$ & $2412.3(8)$ \\
\hline$Z$ & 2 & 4 \\
\hline$D_{\text {calc. }}\left(\mathrm{g} \mathrm{cm}^{-3}\right)$ & 1.302 & 1.683 \\
\hline$\mu\left(\mathrm{Mo}-\mathrm{K}_{\alpha}\right)\left(\mathrm{cm}^{-1}\right)$ & 6.855 & 5.056 \\
\hline$F(000)$ & 480 & 1208 \\
\hline $2 \theta_{\max }$ & 50.0 & 50.0 \\
\hline$h, k, l$ range & $\begin{array}{l}-12 \rightarrow 10,0 \rightarrow 15 \\
0 \rightarrow 11\end{array}$ & $\begin{array}{l}-15 \rightarrow 15,0 \rightarrow 19 \\
0 \rightarrow 13\end{array}$ \\
\hline Reflections collected & 2110 & 2124 \\
\hline Obs. data $[I>2 \sigma(I)]$ & 1797 & 2124 \\
\hline No. of parameters & 244 & 124 \\
\hline$R^{\mathrm{a}}$ & 0.027 & 0.026 \\
\hline$R w^{\mathrm{b}}$ & 0.028 & 0.063 \\
\hline $\begin{array}{l}\text { Transmission (min., } \\
\text { max.) }\end{array}$ & $0.900,1.000$ & $0.205,0.147$ \\
\hline Number of atoms & 57 & 57 \\
\hline Quality-of-fit ${ }^{c}$ & 1.33 & 1.01 \\
\hline $\begin{array}{l}\Delta(\mathrm{D}-\mathrm{map}) \mathrm{max} . / \mathrm{min} . \\
\left(\mathrm{e} \AA^{-3}\right)\end{array}$ & $-0.120 ; 0.190$ & $-0.489 ; 0.688$ \\
\hline
\end{tabular}

pseudo- $C_{2 v}$ symmetry, whereas the anion of $\mathbf{2}$ possesses a $C_{2}$ crystallographic axis through $\mathrm{W}$ and $\mathrm{P}$ atoms and thus has a molecular symmetry of $C_{2 v}$. Complexes 1 and 2 possess two groups of $\mathrm{Cr}-\mathrm{CO}$ bond distances (trans carbonyl 1.876(4), cis carbonyl 1.818(4) $\AA$ (average)) and two group of $\mathrm{W}-\mathrm{CO}$ bond distances of 2.012(6) and 1.927(6) $\AA$. The significantly different bond distances are due to the trans influence of the carbonyl groups.

The dithiocarbamato group of $\mathbf{1}$ exhibits two $\mathrm{C}-\mathrm{S}$ (1.707(4) and 1.717(4) $\AA$ ) and one $\mathrm{C}-\mathrm{N}$ (1.335(4) $\AA$ ) bond lengths and they are nearly identical with those found in the Mo complex, $\left[\mathrm{Et}_{4} \mathrm{~N}\right]\left[\mathrm{Mo}\left(\eta^{2}-\right.\right.$ $\left.\left.\mathrm{S}_{2} \mathrm{CNC}_{5} \mathrm{H}_{10}\right)(\mathrm{CO})_{4}\right] \quad[16] \quad(1.705(4), \quad 1.716(4)$ and $1.336(5) \AA)$ and the $\mathrm{W}$ complex, $\left[\mathrm{Et}_{4} \mathrm{~N}\right]\left[\mathrm{W}\left(\eta^{2}\right.\right.$ $\left.\left.\mathrm{S}_{2} \mathrm{CNC}_{5} \mathrm{H}_{10}\right)(\mathrm{CO})_{4}\right](1.708(7), 1.705(7)$ and 1.335(9) $\AA$ ) as well as $\left[\mathrm{Et}_{4} \mathrm{~N}\right]\left[\mathrm{Mo}\left(\eta^{2}-\mathrm{S}_{2} \mathrm{CNEt}_{2}\right)(\mathrm{CO})_{4}\right]$ (1.692(12), 1.719(13) and 1.329(13) ^) [6] complex within the experimental errors. The two $\mathrm{Cr}-\mathrm{S}$ bond distances (2.4776(13) and 2.4679(12) $\AA$ ) are significantly shorter than the two Mo-S bond distances (2.5898(16) and $2.5978(13) \AA)$ and the two $\mathrm{W}-\mathrm{S}$ bond distances (2.6061(21) and 2.5649(22) $\AA$ ) [8] due to the first row Group VIB metal of the Cr. The short $\mathrm{C}(5)-\mathrm{N}(1)$ bond
Table 2

Selected bond distances $(\AA)$ and angles $\left({ }^{\circ}\right)$ for $\mathbf{1}$

\begin{tabular}{|c|c|c|c|}
\hline \multicolumn{4}{|l|}{ Bond lengths } \\
\hline $\mathrm{Cr}-\mathrm{S}(1)$ & $2.4733(13)$ & $\mathrm{C}(6)-\mathrm{N}(1)$ & $1.458(5)$ \\
\hline $\mathrm{Cr}-\mathrm{S}(2)$ & $2.4730(12)$ & $C(7)-C(8)$ & $1.515(8)$ \\
\hline $\mathrm{Cr}-\mathrm{C}(1)$ & $1.886(5)$ & $\mathrm{C}(8)-\mathrm{C}(9)$ & $1.508(8)$ \\
\hline $\mathrm{Cr}-\mathrm{C}(2)$ & $1.820(4)$ & $\mathrm{C}(9)-\mathrm{C}(10)$ & $1.503(7)$ \\
\hline $\mathrm{Cr}-\mathrm{C}(3)$ & $1.833(4)$ & $\mathrm{C}(10)-\mathrm{N}(1)$ & $1.462(5)$ \\
\hline $\mathrm{Cr}-\mathrm{C}(4)$ & $1.878(5)$ & $\mathrm{C}(1)-\mathrm{O}(1)$ & $1.148(6)$ \\
\hline$S(1)-C(5)$ & $1.707(4)$ & $\mathrm{C}(2)-\mathrm{O}(2)$ & $1.163(5)$ \\
\hline$S(2)-C(5)$ & $1.717(4)$ & $\mathrm{C}(3)-\mathrm{O}(3)$ & $1.152(5)$ \\
\hline $\mathrm{C}(5)-\mathrm{N}(1)$ & $1.334(5)$ & $\mathrm{C}(4)-\mathrm{O}(4)$ & $1.142(6)$ \\
\hline$C(6)-C(7)$ & $1.498(6)$ & & \\
\hline \multicolumn{4}{|l|}{ Bond angles } \\
\hline $\mathrm{S}(1)-\mathrm{Cr}-\mathrm{S}(2)$ & $70.84(4)$ & $S(1)-C(5)-S(2)$ & $113.74(19)$ \\
\hline $\mathrm{S}(1)-\mathrm{Cr}-\mathrm{C}(1)$ & $93.51(13)$ & $\mathrm{S}(1)-\mathrm{C}(5)-\mathrm{N}(1)$ & $123.3(3)$ \\
\hline $\mathrm{S}(1)-\mathrm{Cr}-\mathrm{C}(2)$ & $170.77(14)$ & $\mathrm{S}(2)-\mathrm{C}(5)-\mathrm{N}(1)$ & $122.9(3)$ \\
\hline $\mathrm{S}(1)-\mathrm{Cr}-\mathrm{C}(3)$ & $98.49(14)$ & $\mathrm{C}(7)-\mathrm{C}(6)-\mathrm{N}(1)$ & $110.5(4)$ \\
\hline $\mathrm{S}(1)-\mathrm{Cr}-\mathrm{C}(4)$ & 89.71(14) & $C(6)-C(7)-C(8)$ & $111.7(4)$ \\
\hline $\mathrm{S}(2)-\mathrm{Cr}-\mathrm{C}(1)$ & $92.73(12)$ & $\mathrm{C}(7)-\mathrm{C}(8)-\mathrm{C}(9)$ & $110.6(4)$ \\
\hline $\mathrm{S}(2)-\mathrm{Cr}-\mathrm{C}(2)$ & $99.99(14)$ & $\mathrm{C}(8)-\mathrm{C}(9)-\mathrm{C}(10)$ & $111.2(4)$ \\
\hline $\mathrm{S}(2)-\mathrm{Cr}-\mathrm{C}(3)$ & $169.25(14)$ & $\mathrm{C}(9)-\mathrm{C}(10)-\mathrm{N}(1)$ & $110.6(4)$ \\
\hline $\mathrm{S}(2)-\mathrm{Cr}-\mathrm{C}(4)$ & 89.44(13) & $\mathrm{C}(5)-\mathrm{N}(1)-\mathrm{C}(6)$ & $123.8(3)$ \\
\hline $\mathrm{C}(1)-\mathrm{Cr}-\mathrm{C}(2)$ & $87.93(18)$ & $\mathrm{C}(5)-\mathrm{N}(1)-\mathrm{C}(10)$ & $122.2(3)$ \\
\hline $\mathrm{C}(1)-\mathrm{Cr}-\mathrm{C}(3)$ & $89.14(18)$ & $\mathrm{C}(6)-\mathrm{N}(1)-\mathrm{C}(10)$ & $113.5(3)$ \\
\hline $\mathrm{C}(1)-\mathrm{Cr}-\mathrm{C}(4)$ & $176.57(18)$ & $\mathrm{Cr}-\mathrm{S}(2)-\mathrm{C}(5)$ & $87.44(12)$ \\
\hline $\mathrm{C}(2)-\mathrm{Cr}-\mathrm{C}(3)$ & $90.65(19)$ & $\mathrm{Cr}-\mathrm{C}(1)-\mathrm{O}(1)$ & $174.4(4)$ \\
\hline $\mathrm{C}(2)-\mathrm{Cr}-\mathrm{C}(4)$ & $89.09(18)$ & $\mathrm{Cr}-\mathrm{C}(2)-\mathrm{O}(2)$ & $178.2(4)$ \\
\hline $\mathrm{C}(3)-\mathrm{Cr}-\mathrm{C}(4)$ & 89.21(19) & $\mathrm{Cr}-\mathrm{C}(3)-\mathrm{O}(3)$ & $177.2(4)$ \\
\hline $\mathrm{Cr}-\mathrm{S}(1)-\mathrm{C}(5)$ & $87.65(12)$ & $\mathrm{Cr}-\mathrm{C}(4)-\mathrm{O}(4)$ & $177.6(4)$ \\
\hline
\end{tabular}

length of 1.335(4) $\AA$ in $\mathbf{1}$ indicates considerable partial double bond character as is typical for the chelating 1,1dithiolate ligands [17].

The $\mathrm{W}-\mathrm{S}$ bond distance of 2.6102(14) $\AA$ in 2 is longer than those found in the dithiocarbamate complexes $\left[\mathrm{Et}_{4} \mathrm{~N}\right]\left[\mathrm{W}\left(\eta^{2}-\mathrm{S}_{2} \mathrm{CNC}_{4} \mathrm{H}_{8}\right)(\mathrm{CO})_{4}\right]$ (average value of $\mathrm{W}-\mathrm{S}$ bonds, $2.590(3) \AA)$ and $\left[\mathrm{Et}_{4} \mathrm{~N}\right]\left[\mathrm{W}\left(\eta^{2}-\mathrm{S}_{2} \mathrm{CNC}_{5} \mathrm{H}_{10}\right)(\mathrm{CO})_{4}\right]$ (2.5855(22) $\AA$ ). It reflects the large $\pi$ accepting ability of $\mathrm{R}_{2} \mathrm{NCS}_{2}^{-}$ligand than the (EtO) ${ }_{2} \mathrm{PS}_{2}^{-}$ligand. In fact, the $(\mathrm{EtO})_{2} \mathrm{PS}_{2}^{-}$ligand can be replaced by the $\mathrm{Et}_{2} \mathrm{NCS}_{2}^{-}$ ligand under some reaction conditions [8]. The SWS(a) angle $76.07(7)^{\circ}$ of 2 is similar to the angle $76.5(1)^{\circ}$ in the complex $\left[\mathrm{CpMo}\left\{\eta^{2}-\mathrm{S}_{2} \mathrm{P}(\mathrm{OEt})_{2}\right\}(\mathrm{CO})_{2}\right], 77.32(5)^{\circ}$ in the complex $\quad\left[\mathrm{Mo}\left(\eta^{3}-\mathrm{C}_{3} \mathrm{H}_{5}\right)(\mathrm{CO})_{2}\left\{\eta^{2}-\mathrm{S}_{2} \mathrm{P}(\mathrm{OEt})_{2}\right\}\right]_{2}(\mu-$ $\left.\mathrm{NH}_{2} \mathrm{NH}_{2}\right)$ and $75.87(5)^{\circ}$ in the complex $\left[\mathrm{Et}_{4} \mathrm{~N}\right]\left[\mathrm{Mo}\left\{\eta^{2}-\right.\right.$ $\left.\left.\mathrm{S}_{2} \mathrm{P}(\mathrm{OEt})_{2}(\mathrm{CO})_{4}\right]\right]$ [8] which are all within the experimental errors. Other important bond distances and angles of dithiocarbamate and dithiophosphate VIB metal complexes are listed in Table 6.

\subsection{Synthesis of complex $\left[\mathrm{W}\left(\mathrm{CH}_{3} \mathrm{CN}\right)\left(\eta^{3}\right.\right.$ - $\left.\left.\mathrm{C}_{3} \mathrm{H}_{5}\right)(\mathrm{CO})_{2}\left\{\eta^{2}-\mathrm{S}_{2} \mathrm{P}(\mathrm{OEt})_{2}\right\}\right]$ (3)}

In an attempt to synthesize the allyl dithiophosphate $\mathrm{W}$ complex as that in Mo system [8], we treated of $\left[\mathrm{Et}_{4} \mathrm{~N}\right]\left[\mathrm{W}\left\{\eta^{2}-\mathrm{S}_{2} \mathrm{P}(\mathrm{OEt})_{2}(\mathrm{CO})_{4}\right\}\right]$ (2) with allyl bromide in $\mathrm{CH}_{3} \mathrm{CN}$ at room temperature. However, there was no reaction but decomposed in the refluxing temperature. 
However, complex $\left[\mathrm{W}\left(\mathrm{CH}_{3} \mathrm{CN}\right)\left(\eta^{3}-\mathrm{C}_{3} \mathrm{H}_{5}\right)(\mathrm{CO})_{2}\left\{\eta^{2}-\right.\right.$ $\left.\left.\mathrm{S}_{2} \mathrm{P}(\mathrm{OEt})_{2}\right\}\right]$ (3) can be obtained from the reaction of $\left[\mathrm{W}\left(\mathrm{CH}_{3} \mathrm{CN}\right)_{2}\left(\eta^{3}-\mathrm{C}_{3} \mathrm{H}_{5}\right)(\mathrm{CO})_{2} \mathrm{Br}\right]$ and $\mathrm{NH}_{4}(\mathrm{EtO})_{2} \mathrm{PS}_{2}$ at room temperature with $82 \%$ yield (Scheme 1). The complex 3 is analogous to the dithiophosphate complex $\left[\mathrm{Mo}\left(\mathrm{CH}_{3} \mathrm{CN}\right)\left(\eta^{3}-\mathrm{C}_{3} \mathrm{H}_{5}\right)(\mathrm{CO})_{2}\left\{\eta^{2}-\mathrm{S}_{2} \mathrm{P}(\mathrm{OEt})_{2}\right\}\right] \quad[8]$, which is also crystallographically characterized. The solution phase IR spectrum shows two carbonyl bands at 1936 and $1840 \mathrm{~cm}^{-1}$ with equal intensity; this observation indicates that the two carbonyls are mutually cis. The room temperature ${ }^{1} \mathrm{H}-\mathrm{NMR}$ spectrum shows a broad signal at $\delta 2.32$ (methyl resonance of $\mathrm{CH}_{3} \mathrm{CN}$ ), an $\mathrm{AM}_{2} \mathrm{X}_{2}$ pattern of the allyl group and one equivalent resonance of the terminal carbon of the allyl group and one resonance of carbonyl group in the ${ }^{13} \mathrm{C}\left\{{ }^{1} \mathrm{H}\right\}$-NMR spectrum, which suggests a similar intramolecular trigonal twist solution behavior to that of the crystallographically determined complex $\left[\mathrm{Mo}\left(\mathrm{CH}_{3} \mathrm{CN}\right)\left(\eta^{3}-\mathrm{C}_{3} \mathrm{H}_{5}\right)(\mathrm{CO})_{2}\left\{\eta^{2}-\mathrm{S}_{2} \mathrm{P}(\mathrm{OEt})_{2}\right\}\right]$ as shown, with one of the sulfur atom of the dithiophosphate ligand being trans to the allyl group.

The variable-temperature ${ }^{1} \mathrm{H}-\mathrm{NMR}$ experiments of 3 were used to investigate the solution behavior. On cooling the $\mathrm{CDCl}_{3}$ solutions of $\mathbf{3}$, the proton signals initially broaden and below $233 \mathrm{~K}$ the methyl resonance of $\mathrm{CH}_{3} \mathrm{CN}$ and the syn- and anti-proton signals of the allyl moiety each begin to separate into two components. The intramolecular trigonal twist mechanism has been previously described for $\left[\mathrm{Mo}(\mathrm{pd})\left(\eta^{3}-\right.\right.$ $\left.\left.\mathrm{C}_{3} \mathrm{H}_{5}\right)(\mathrm{CO})_{2}(\mathrm{py})\right] \quad[11 \mathrm{~b}], \quad\left[\mathrm{Mo}\left(\mathrm{CH}_{3} \mathrm{CN}\right)\left(\eta^{3}-\right.\right.$ $\left.\left.\mathrm{C}_{3} \mathrm{H}_{5}\right)(\mathrm{CO})_{2}\left\{\eta^{2}-\mathrm{S}_{2} \mathrm{P}(\mathrm{OEt})_{2}\right\}\right][8]$ and other related complexes [10]. The line-shapes calculated from variabletemperature ${ }^{1} \mathrm{H}$-NMR spectra of $\mathbf{3}$ yields a value of $11.5 \pm 0.2 \mathrm{kcal} \mathrm{mol}^{-1}$ for $\Delta G^{\ddagger}$. Compared with other rearrangement complexes, the activation energy of $\mathbf{3}$ is similar to that of complex $\left[\mathrm{Mo}\left(\mathrm{CH}_{3} \mathrm{CN}\right)\left(\eta^{3}-\right.\right.$ $\left.\left.\mathrm{C}_{3} \mathrm{H}_{5}\right)(\mathrm{CO})_{2}\left\{\eta^{2}-\mathrm{S}_{2} \mathrm{P}(\mathrm{OEt})_{2}\right\}\right]\left(11.6 \mathrm{kcal} \mathrm{mol}^{-1}\right)$ [8], is larger than that of complex $\left[\mathrm{W}\left(\eta^{3}-\mathrm{C}_{3} \mathrm{H}_{5}\right)(\mathrm{CO})_{2}(\mathrm{dppe}) \mathrm{I}\right]$ $\left(10.7 \mathrm{kcal} \mathrm{mol}^{-1}\right)$ [11a] and is smaller than that of complex $\left[\mathrm{Mo}(\mathrm{pd})\left(\eta^{3}-\mathrm{C}_{3} \mathrm{H}_{5}\right)(\mathrm{CO})_{2}(\mathrm{py})\right] \quad(14.3 \quad \mathrm{kcal}$ $\left.\mathrm{mol}^{-1}\right)[11 \mathrm{~b}]$.

\subsection{Reaction of complex $\left[\mathrm{W}\left(\mathrm{CH}_{3} \mathrm{CN}\right)\left(\eta^{3}\right.\right.$ - $\left.\left.\mathrm{C}_{3} \mathrm{H}_{5}\right)(\mathrm{CO})_{2}\left\{\eta^{2}-\mathrm{S}_{2} \mathrm{P}(\mathrm{OEt})_{2}\right\}\right]$ (3) with dppe}

In order to compare the reactivity of $\left[\mathrm{W}\left(\mathrm{CH}_{3} \mathrm{CN}\right)\left(\eta^{3}\right.\right.$ $\left.\left.\mathrm{C}_{3} \mathrm{H}_{5}\right)(\mathrm{CO})_{2}\left\{\eta^{2}-\mathrm{S}_{2} \mathrm{P}(\mathrm{OEt})_{2}\right\}\right](3)$ and Mo analogue and to synthesize the $\eta^{3}$-allyl endo, exo-stereoisomer [18] we have attempted the following reactions.

In the reaction of 3 with dppe, on adding $\mathrm{CH}_{2} \mathrm{Cl}_{2}$ solution of dppe to $\mathbf{3}$, the dppe bridged dinuclear complex $\left[\mathrm{W}\left(\eta^{3}-\mathrm{C}_{3} \mathrm{H}_{5}\right)(\mathrm{CO})_{2}\left\{\eta^{2}-\mathrm{S}_{2} \mathrm{P}(\mathrm{OEt})_{2}\right\}\right]_{2}(\mu$-dppe $)$ (4) and $\eta^{1}$-dppe complex $\left[\mathrm{W}\left(\eta^{3}-\mathrm{C}_{3} \mathrm{H}_{5}\right)(\mathrm{CO})_{2}\left\{\eta^{2}\right.\right.$ $\left.\mathrm{S}_{2} \mathrm{P}(\mathrm{OEt})_{2}\right\}\left(\eta^{1}\right.$-dppe $\left.)\right](5)$ were obtained. The ratio of 4 to 5 was $4: 1$. An equimolar amount of a $\mathrm{CH}_{2} \mathrm{Cl}_{2}$ solution of dppe was added at room temperature to a
$\mathrm{CH}_{2} \mathrm{Cl}_{2}$ solution of 3 slowly, the mononuclear complex $\left[\mathrm{W}\left(\eta^{3}-\mathrm{C}_{3} \mathrm{H}_{5}\right)(\mathrm{CO})_{2}\left\{\eta^{2}-\mathrm{S} 2 \mathrm{P}(\mathrm{OEt})_{2}\right\}\right]_{2}(\mu$-dppe $)$ (4) was obtained as the sole product. The yellow compounds 4 and $\mathbf{5}$ are very air-stable and soluble in polar solvents. The FAB mass spectra of $\mathbf{4}$ show a parent peak corresponding to the $\left[\mathrm{M}^{+}\right]$molecular mass. The solution phase IR spectrum (in $\mathrm{CH}_{2} \mathrm{Cl}_{2}$ ) shows the two carbonyls with equal intensity, which indicates that the two carbonyls are mutually cis. The ${ }^{31} \mathrm{P}\left\{{ }^{1} \mathrm{H}\right\}$ spectrum of 4 in $\mathrm{CDCl}_{3}$ shows a resonance at $\delta 32.1$ with a tungsten satellite $(J(\mathrm{WP}) 101.4 \mathrm{~Hz})$, indicating phosphorus co-ordination of the dppe ligand and $\delta 108.5(\mathrm{t}$, $J(\mathrm{PP}) 20.2 \mathrm{~Hz}$ ) for the dithiophosphate ligand. The ${ }^{13} \mathrm{C}\left\{{ }^{1} \mathrm{H}\right\}$-NMR spectrum of $\mathbf{4}$ reveals one doublet at the lowest field $\left(\delta 214.2\left(\mathrm{~d},{ }^{2} J(\mathrm{PC}) 7.7 \mathrm{~Hz}\right)\right.$, which is assigned to the terminal carbonyl groups. From an $\mathrm{AM}_{2} \mathrm{X}_{2}$ pattern of the allyl group in the ${ }^{1} \mathrm{H}-\mathrm{NMR}$ spectra and one equivalent resonance of the terminal carbon of the allyl group and one resonance of carbonyl group in the ${ }^{13} \mathrm{C}\left\{{ }^{1} \mathrm{H}\right\}$-NMR spectra, it seems that the dithiophosphato bidentate ligand and the two carbonyls lie in a horizontal plane, whereas the allyl group and the one phosphorus atom of the dppe ligand lie in trans positions above and below the plane. The two ' $\mathrm{W}\left(\mathrm{\eta}^{3}\right.$ $\left.\mathrm{C}_{3} \mathrm{H}_{5}\right)(\mathrm{CO})_{2}\left\{\eta^{2}-\mathrm{S}_{2} \mathrm{P}(\mathrm{OEt})_{2}\right\}$ ' fragments were held together by a dppe ligand which is the only bridge between the two $\mathrm{W}$ atoms and suggests a structure different from that of the crystallographically determined complex $\left[\mathrm{Mo}\left(\eta^{3}-\mathrm{C}_{3} \mathrm{H}_{5}\right)(\mathrm{CO})_{2}\left\{\eta^{2}-\mathrm{S}_{2} \mathrm{P}(\mathrm{OEt})_{2}\right\}\right]_{2}\left(\mu-\mathrm{NH}_{2} \mathrm{NH}_{2}\right)[11]$.

If an equimolar amount of a $\mathrm{CH}_{2} \mathrm{Cl}_{2}$ solution of $\mathbf{3}$ was added at room temperature to a $\mathrm{CH}_{2} \mathrm{Cl}_{2}$ solution of dppe slowly, the mononuclear complex $\left[\mathrm{W}\left(\eta^{3}-\right.\right.$ $\left.\mathrm{C}_{3} \mathrm{H}_{5}\right)(\mathrm{CO})_{2}\left\{\eta^{2}-\mathrm{S}_{2} \mathrm{P}(\mathrm{OEt})_{2}\right\}\left(\eta^{1}\right.$-dppe $\left.)\right](5)$ was obtained as the sole product. The FAB mass spectrum of $\mathbf{5}$ shows a base peak at $m / z 864$. The IR spectrum of 5 shows two carbonyl stretchings at 1934 and $1843 \mathrm{~cm}^{-1}$ with equal intensities, suggesting that the open face of the allyl is directed towards the two carbonyls as found in other structures of $\left(\eta^{3}-\mathrm{C}_{3} \mathrm{H}_{5}\right)$ dicarbonylmolybdenum complexes [10c]. The ${ }^{31} \mathrm{P}\left\{{ }^{1} \mathrm{H}\right\}$ spectrum of $\mathbf{5}$ exhibits a resonance at $\delta 30.3$ with a tungsten satellite ( $J(\mathrm{WP}) 99.0$ $\mathrm{Hz}$ ), indicating phosphorus co-ordination of the dppe ligand. Upon refluxing $\mathrm{CH}_{3} \mathrm{CN}$ for $72 \mathrm{~h}$, no carbon monoxide was released to form the $\eta^{2}$-dppe endo, exostereoisomers complexes $\left[\mathrm{W}\left(\eta^{3}-\mathrm{C}_{3} \mathrm{H}_{5}\right)(\mathrm{CO})\left\{\eta^{2}\right.\right.$ $\left.\mathrm{S}_{2} \mathrm{P}(\mathrm{OEt})_{2}\right\}\left(\eta^{2}\right.$-dppe $\left.)\right]$ in the case of complexes $\mathbf{5}, \mathbf{3}$ and dppe.

\subsection{Conclusion}

The structures of first dithiocarbamate $\operatorname{Cr}(0)(\mathbf{1})$ and dithiophosphate $\mathrm{W}(0)$ (2) have been determined by Xray diffraction analyses. In the dithiophosphate complexes, the stability in $\mathrm{W}$ is larger than Mo but less soluble than those of Mo analogue. Complex $\left[\mathrm{W}\left(\mathrm{CH}_{3} \mathrm{CN}\right)\left(\eta^{3}-\mathrm{C}_{3} \mathrm{H}_{5}\right)(\mathrm{CO})_{2}\left\{\eta^{2}-\mathrm{S}_{2} \mathrm{P}(\mathrm{OEt})_{2}\right\}\right](3)$ reacted 
with dppe in $\mathrm{CH}_{2} \mathrm{Cl}_{2}$ at room temperature to give a mixture of dinuclear dppe bridged complex $\left[\mathrm{W}\left(\eta^{3}-\right.\right.$ $\left.\left.\mathrm{C}_{3} \mathrm{H}_{5}\right)(\mathrm{CO})_{2}\left\{\eta^{2}-\mathrm{S}{ }_{2} \mathrm{P}(\mathrm{OEt})_{2}\right\}\right]_{2}(\mu$-dppe $)$ (4) and $\left[\mathrm{W}\left(\eta^{3}-\right.\right.$ $\left.\mathrm{C}_{3} \mathrm{H}_{5}\right)(\mathrm{CO})_{2}\left\{\eta^{2}-\mathrm{S}_{2} \mathrm{P}(\mathrm{OEt})_{2}\right\}\left(\eta^{1}\right.$-dppe $\left.)\right]$ (5). The variable-temperature ${ }^{1} \mathrm{H}$-NMR experiments were used to confirm the intramolecular trigonal twist rotational behavior of $\mathbf{3}$ in the solution state.

\section{Experimental}

\subsection{Materials}

All manipulations were performed under nitrogen using vacuum-line, drybox, and standard Schlenk techniques. NMR spectra were recorded on an AM-500 WB FT-NMR spectrometer and are reported in units of $\delta$ (ppm) with residual protons in the solvent as an internal standard $\left(\mathrm{CDCl}_{3}, \delta 7.24 ; \mathrm{CD}_{3} \mathrm{CN}, \delta 1.93 ; \mathrm{C}_{6} \mathrm{D}_{6}, \delta 7.15\right.$; $\mathrm{C}_{2} \mathrm{D}_{6} \mathrm{CO}, \delta$ 2.04). IR spectra were measured on a Nicolate Avator-320 instrument and were referenced to a polystyrene standard, using cells equipped with calcium fluoride windows. Mass spectra were recorded on a JEOL SX-102A spectrometer. Solvents were dried and deoxygenated by refluxing over the appropriate reagents before use. $n$-Hexane, diethyl ether, THF and benzene were distilled from sodium-benzophenone. Acetonitrile, dichloromethane were distilled from calcium hydride, and methanol from magnesium. All other solvents and reagents were of reagent grade and were used as received. Metal carbonyls, allyl bromide and $\mathrm{NH}_{4} \mathrm{~S}_{2} \mathrm{P}(\mathrm{OEt})_{2}$ were purchased from Strem, Merck and Janssen, respectively. The compounds $\left[\mathrm{Et}_{4} \mathrm{~N}\right]\left[\mathrm{Cr}\left(\eta^{2}\right.\right.$ $\left.\left.\mathrm{S}_{2} \mathrm{CNC}_{5} \mathrm{H}_{10}\right)(\mathrm{CO})_{4}\right] \quad[15]$ and $\left[\mathrm{Et}_{4} \mathrm{~N}\right]\left[\mathrm{W}\left\{\eta^{2}\right.\right.$ $\left.\mathrm{S}_{2} \mathrm{P}(\mathrm{OEt})_{2}(\mathrm{CO})_{4}\right]$ [8] were prepared according to the literature methods. Elemental analyses and X-ray diffraction studies were carried out at the Regional Center of Analytical Instrument located at the National Taiwan University.

\section{2. (Acetonitrile) $\left(\eta^{3}\right.$-allyl) (dicarbonyl) $\left(\eta^{2}\right.$ - diethyldithiophosphato)tungsten(II) (3)}

Ten milliliter of $\mathrm{CH}_{2} \mathrm{Cl}_{2}$ was added to a $100 \mathrm{ml}$ flask containing $\left[\mathrm{W}\left(\mathrm{CH}_{3} \mathrm{CN}\right)_{2}\left(\eta^{3}-\mathrm{C}_{3} \mathrm{H}_{5}\right)(\mathrm{CO})_{2}(\mathrm{Br})\right](0.442 \mathrm{~g}$, $1.0 \mathrm{mmol})$ and $\left[\mathrm{NH}_{4}\right]\left[\mathrm{S}_{2} \mathrm{P}(\mathrm{OEt})_{2}\right](0.203 \mathrm{~g}, 1.0 \mathrm{mmol})$ at ambient temperature. After stirring for $10 \mathrm{~min}$, the solvent was removed in vacuo. The residue was abstracted by diethyl ether $(2 \times 5 \mathrm{ml})$. $n$-Hexane $(40$ $\mathrm{ml}$ ) was added to the solution and a yellow-orange precipitate was formed. The precipitate was collected by filtration (G4) washed with cold $n$-hexane $(2 \times 10 \mathrm{ml})$ and then dried in vacuo yielding $0.42 \mathrm{~g}(82 \%)$ of 3 . Recrystallizations using a mixture of cold 20/1 nhexane-diethyl ether give the yellow-orange crystalline product $\quad\left[\mathrm{W}\left(\mathrm{CH}_{3} \mathrm{CN}\right)\left(\eta^{3}-\mathrm{C}_{3} \mathrm{H}_{5}\right)(\mathrm{CO})_{2}\left\{\eta^{2}-\mathrm{S}_{2} \mathrm{P}(\mathrm{OEt})_{2}\right\}\right]$
(3). IR $\left(\mathrm{CH}_{3} \mathrm{CN}\right) v(\mathrm{CO})$ 1936(vs), 1840(vs); (KBr) $v$ (CO) 1916(vs), 1824(vs) cm ${ }^{-1} \cdot{ }^{31} \mathrm{P}\left\{{ }^{1} \mathrm{H}\right\}-\mathrm{NMR}$ (202 $\left.\mathrm{MHz}, \mathrm{CDCl}_{3}, 298 \mathrm{~K}\right): \delta$ 108.9. ${ }^{1} \mathrm{H}-\mathrm{NMR}(500 \mathrm{MHz}$, $\left.\mathrm{CDCl}_{3}, 298 \mathrm{~K}\right): \delta 1.41\left(\mathrm{t},{ }^{3} J(\mathrm{HH}) 7.1 \mathrm{~Hz}, 6 \mathrm{H}\right.$, $\left.\mathrm{OCH}_{2} \mathrm{CH}_{3}\right), 1.52(\mathrm{~d}, J(\mathrm{HH}) 8.9 \mathrm{~Hz}, 2 \mathrm{H}$, Hanti of allyl), 2.32 (s, $3 \mathrm{H}, \mathrm{CH}_{3} \mathrm{CN}$ ), 3.06 (br, $2 \mathrm{H}, \mathrm{Hsyn}$ of allyl), 3.35 $(\mathrm{m}, 1 \mathrm{H}, \mathrm{CH}$ of allyl), $4.44(\mathrm{q}, J(\mathrm{HH}) 7.1 \mathrm{~Hz}, 4 \mathrm{H}$, $\left.\mathrm{OCH}_{2}\right) .{ }^{13} \mathrm{C}\left\{{ }^{1} \mathrm{H}\right\}$-NMR $\left(125 \mathrm{MHz}, \mathrm{CDCl}_{3}, 298 \mathrm{~K}\right): \delta 3.3$ (s, $\left.\mathrm{CH}_{3} \mathrm{CN}\right), 15.8\left(\mathrm{~s}, \mathrm{OCH}_{2} \mathrm{CH}_{3}\right), 56.7\left(\mathrm{~s}, \mathrm{CH}=\mathrm{CH}_{2}\right)$, $63.9\left(\mathrm{~s}, \mathrm{OCH}_{2}\right), 75.5\left(\mathrm{~s}, \mathrm{CH}_{2}=\mathrm{CH}\right), 119.5\left(\mathrm{~s}, \mathrm{CH}_{3} \mathrm{CN}\right)$, 220.0 (s, CO). MS (FAB, NBA): $m / z 507\left[\mathrm{M}^{+}\right], 466$ $\left[\mathrm{M}^{+}-\mathrm{CH}_{3} \mathrm{CN}\right], \quad 425 \quad\left[\mathrm{M}^{+}-\mathrm{CH}_{3} \mathrm{CN}-\mathrm{C}_{3} \mathrm{H}_{5}\right], \quad 397$ $\left[\mathrm{M}^{+}-\mathrm{CH}_{3} \mathrm{CN}-\mathrm{C}_{3} \mathrm{H}_{5}-\mathrm{CO}\right], \quad 369 \quad\left[\mathrm{M}^{+}-\mathrm{CH}_{3} \mathrm{CN}-\right.$ $\mathrm{C}_{3} \mathrm{H}_{5}-2 \mathrm{CO}$. Anal. Calc. for $\mathrm{C}_{11} \mathrm{H}_{18} \mathrm{NO}_{4} \mathrm{PS}_{2} \mathrm{~W}$ : C, 26.04; H, 3.58; N, 2.76. Found: C, 26.34; H, 3.72; N, $2.98 \%$.

\subsection{Bis- $\left[\left(\eta^{3}-\right.\right.$ Allyl $)($ dicarbonyl $)\left(\eta^{2}-\right.$}

diethyldithiophosphato)tungsten(II)] [ $\mu$-bis-\{(diphenylphosphine)ethane\} (4)

\subsubsection{Method A}

Two milliliter $\mathrm{CH}_{2} \mathrm{Cl}_{2}$ solution of dppe $(0.396 \mathrm{~g}, 1.0$ mmol) was added to a flask containing a solution of $\mathbf{3}$ $(0.523 \mathrm{~g}, 1.0 \mathrm{mmol})$ in $\mathrm{MeCN}(20 \mathrm{ml})$. After stirring for $10 \mathrm{~min}$, a yellow-orange precipitate was formed. The precipitate was collected by filtration (G4) washed with $n$-hexane $(2 \times 10 \mathrm{ml})$ and then dried in vacuo yielding $0.70 \mathrm{~g}(51 \%)$ of 4 and $0.17 \mathrm{~g}(19 \%)$ of $\mathbf{5}$. Recrystallizations using a mixture of $20 / 1 n$-hexane- $-\mathrm{CH}_{2} \mathrm{Cl}_{2}$ give a mixture of yellow-orange crystalline products $\left[\mathrm{W}\left(\eta^{3}\right.\right.$ $\left.\left.\mathrm{C}_{3} \mathrm{H}_{5}\right)(\mathrm{CO})_{2}\left\{\eta^{2}-\mathrm{S} \mathrm{S}_{2} \mathrm{P}(\mathrm{OEt})_{2}\right\}\right]_{2}(\mu-\mathrm{dppe})(\mathbf{4})$ and $\mathbf{5}$.

\subsubsection{Method $B$}

Dppe (0.198 g, $0.5 \mathrm{mmol})$ was dissolved in $\mathrm{CH}_{2} \mathrm{Cl}_{2}(5$ $\mathrm{ml}$ ) and the solution was added slowly to a flask containing a solution of $3(0.523 \mathrm{~g}, 1.0 \mathrm{mmol})$ in $\mathrm{CH}_{2} \mathrm{Cl}_{2}(10 \mathrm{ml})$ during a period of $5 \mathrm{~min}$. The solution was stirred for $10 \mathrm{~min}$ and the solvent was removed in vacuo till about $5 \mathrm{ml}$. Methanol $(15 \mathrm{ml})$ was added to the flask and the solution was stored at $-18{ }^{\circ} \mathrm{C}$ for $12 \mathrm{~h}$ to give yellow precipitates. The precipitate was collected by filtration (G4) washed with $n$-hexane $(2 \times 10 \mathrm{ml})$ and then dried in vacuo yielding $0.69 \mathrm{~g}(96 \%)$ of 4 Spectroscopic data of 4: IR (KBr) $v$ (CO) 1937(vs), 1857(vs) $\mathrm{cm}^{-1} \cdot{ }^{31} \mathrm{P}\left\{{ }^{1} \mathrm{H}\right\}$-NMR $\left(202 \mathrm{MHz}, \mathrm{CDCl}_{3}, 298 \mathrm{~K}\right): \delta 32.1$ (dt, $\left.{ }^{3} J(\mathrm{PP}) 20.2 \mathrm{~Hz}, J(\mathrm{WP}) 101.4 \mathrm{~Hz}\right), 108.5$ (t, $J(\mathrm{PP})$ $20.2 \mathrm{~Hz}, \mathrm{PS}_{2}$ ). ${ }^{1} \mathrm{H}-\mathrm{NMR}\left(500 \mathrm{MHz}, \mathrm{CDCl}_{3}, 298 \mathrm{~K}\right): \delta$ $1.10\left(\mathrm{t},{ }^{3} J(\mathrm{HH}) 9.7 \mathrm{~Hz}, 12 \mathrm{H}, \mathrm{OCH}_{2} \mathrm{CH}_{3}\right), 1.76(\mathrm{~d}$, $J(\mathrm{HH}) 9.7 \mathrm{~Hz}, 4 \mathrm{H}$, Hanti of allyl), 2.30, $2.81(\mathrm{~m}, 4 \mathrm{H}$, $\left.\mathrm{PCH}_{2}\right), 3.48$ (m, 2H, CH of allyl), 3.56 (m, 4H, Hsyn of allyl), $3.72\left(\mathrm{~m}, 8 \mathrm{H}, \mathrm{OCH}_{2}\right) .{ }^{13} \mathrm{C}\left\{{ }^{1} \mathrm{H}\right\}-\mathrm{NMR}(125 \mathrm{MHz}$, $\left.\mathrm{CDCl}_{3}, 298 \mathrm{~K}\right): \delta 15.8\left(\mathrm{~d},{ }^{3} \mathrm{~J}(\mathrm{PC}) 8.6 \mathrm{~Hz}, \mathrm{OCH}_{2} \mathrm{CH}_{3}\right)$, $26.3\left(\mathrm{dd}, J(\mathrm{PC}) 11.6,11.1 \mathrm{~Hz}, \mathrm{PCH}_{2}\right), 50.9$ (br, $\mathrm{CH}=$ $\left.\mathrm{CH}_{2}\right), 62.0\left(\mathrm{~d},{ }^{2} \mathrm{~J}(\mathrm{PC}) 6.8 \mathrm{~Hz}, \mathrm{OCH}_{2}\right), 74.2\left(\mathrm{~s}, \mathrm{CH}_{2}=\right.$ $C \mathrm{H}), 214.6\left(\mathrm{~d},{ }^{2} J(\mathrm{PC}) 7.7 \mathrm{~Hz}, C \mathrm{O}\right)$. MS (FAB, NBA): 
$\mathrm{m} / \mathrm{z} 1331\left[\mathrm{M}^{+}\right], 1219\left[\mathbf{M}^{+}-4 \mathrm{CO}\right]$. Anal. Calc. for $\mathrm{C}_{44} \mathrm{H}_{54} \mathrm{O}_{8} \mathrm{P}_{4} \mathrm{~S}_{4} \mathrm{~W}_{2}$ : C, 39.71; $\mathrm{H}, 4.09$. Found: C, 39.84; $\mathrm{H}, 4.21 \%$.

\section{4. $\left(\eta^{3}\right.$-Allyl) (dicarbonyl) $\left(\eta^{2}-\right.$} diethyldithiophosphato) $\left[\eta^{1}\right.$-bis\{(diphenylphosphino)ethane $\}]$ tungsten (II) (5)

Ten milliliter of $\mathrm{CH}_{2} \mathrm{Cl}_{2}$ solution of $3(0.523 \mathrm{~g}, 1.0$ mmol) was added slowly to a $100 \mathrm{ml}$ flask containing dppe $(0.396 \mathrm{~g}, 1.0 \mathrm{mmol})$ in $\mathrm{CH}_{2} \mathrm{Cl}_{2}(10 \mathrm{ml})$ during a period of $5 \mathrm{~min}$ at room temperature. A yellow-orange precipitate was formed. The precipitate was collected by filtration (G4) washed with $n$-hexane $(2 \times 10 \mathrm{ml})$ and then dried in vacuo yielding $0.87 \mathrm{~g}(95 \%)$ of (5). Recrystallization using a mixture of $20 / 1 n$-hexane$\mathrm{CH}_{2} \mathrm{Cl}_{2}$ to give the yellow-orange crystalline product $\left[\mathrm{W}\left(\eta^{3}-\mathrm{C}_{3} \mathrm{H}_{5}\right)(\mathrm{CO})_{2}\left\{\eta^{2}-\mathrm{S}_{2} \mathrm{P}(\mathrm{OEt})_{2}\right\}\left(\eta^{1}\right.\right.$-dppe $\left.)\right] \quad$ (5). IR (KBr) v (CO) 1934(vs), 1843(vs) cm ${ }^{-1} \cdot{ }^{31} \mathrm{P}\left\{{ }^{1} \mathrm{H}\right\}$-NMR $\left(202 \mathrm{MHz}, \mathrm{CDCl}_{3}, 298 \mathrm{~K}\right.$ ): $\delta 30.3$ (t, $J(\mathrm{WP}) 99.0 \mathrm{~Hz}$, $\left.\mathrm{WPCH}_{2}\right), 57.2\left(\mathrm{br}, \mathrm{PCH}_{2}\right), 103.1$ (br, $\left.\mathrm{PS}_{2}\right) .{ }^{1} \mathrm{H}-\mathrm{NMR}$ $\left(500 \mathrm{MHz}, \mathrm{CDCl}_{3}, 298 \mathrm{~K}\right): \delta 1.11,1.23\left(\mathrm{t},{ }^{3} J(\mathrm{HH}) 7.1\right.$ $\left.\mathrm{Hz}, 6 \mathrm{H}, \mathrm{OCH}_{2} \mathrm{CH}_{3}\right), 1.84(\mathrm{~d}, J(\mathrm{HH}) 9.5 \mathrm{~Hz}, 2 \mathrm{H}$, Hanti of allyl), $2.28\left(\mathrm{~m}, 4 \mathrm{H}, \mathrm{PCH}_{2}\right), 3.23\left(\mathrm{~m}, 4 \mathrm{H}, \mathrm{OCH}_{2}\right), 3.50$ (d, $J(\mathrm{HH}) 5.3 \mathrm{~Hz}, 2 \mathrm{H}$, Hsyn of allyl), $4.23(\mathrm{~m}, 1 \mathrm{H}, \mathrm{CH}$ of allyl). ${ }^{13} \mathrm{C}\left\{{ }^{1} \mathrm{H}\right\}$-NMR $\left(125 \mathrm{MHz}, \mathrm{CDCl}_{3}, 298 \mathrm{~K}\right): \delta$ $16.4\left(\mathrm{~d},{ }^{3} \mathrm{~J}(\mathrm{PC}) 9.2 \mathrm{~Hz}, \mathrm{OCH}_{2} \mathrm{CH}_{3}\right), 27.3(\mathrm{dd}, J(\mathrm{PC}) 11.6$ $\left.\mathrm{Hz}, \mathrm{PCH}_{2}\right), 52.1\left(\mathrm{br}, \mathrm{CH}=\mathrm{CH}_{2}\right), 63.9,64.8\left(\mathrm{~s}, \mathrm{OCH}_{2}\right)$, $73.3\left(\mathrm{~s}, \mathrm{CH}_{2}=\mathrm{CH}\right), 214.6\left(\mathrm{t},{ }^{2} J(\mathrm{PC}) 8.7 \mathrm{~Hz}, \mathrm{CO}\right) . \mathrm{MS}$ (FAB, NBA): $m / z 864\left[\mathrm{M}^{+}\right], 836\left[\mathrm{M}^{+}-\mathrm{CO}\right], 808$ $\left[\mathrm{M}^{+}-2 \mathrm{CO}\right], 767\left[\mathrm{M}^{+}-2 \mathrm{CO}-\mathrm{C}_{3} \mathrm{H}_{5}\right]$. Anal. Calc. for $\mathrm{C}_{35} \mathrm{H}_{39} \mathrm{O}_{4} \mathrm{P}_{3} \mathrm{~S}_{2} \mathrm{~W}: \mathrm{C}, 48.62 ; \mathrm{H}, 4.55$. Found: $\mathrm{C}, 48.84 ; \mathrm{H}$, $4.78 \%$

Table 3

Atomic coordinates $\left(\times 10^{4}\right)$ and equivalent isotropic displacement coefficients $\left(\AA^{2} \times 10^{3}\right)$ for important atoms of 1

\begin{tabular}{lllll}
\hline Atom & \multicolumn{1}{l}{$y$} & $z$ & $B_{\mathrm{eg}}$ \\
\hline $\mathrm{Cr}$ & $0.19514(6)$ & 0.50000 & $0.32111(6)$ & $3.63(3)$ \\
$\mathrm{S} 1$ & $0.36209(11)$ & $0.42891(10)$ & $0.57523(11)$ & $4.09(5)$ \\
S2 & $0.16560(11)$ & $0.60306(9)$ & $0.51752(11)$ & $3.77(5)$ \\
C1 & $0.0410(5)$ & $0.4073(4)$ & $0.2938(4)$ & $4.22(21)$ \\
C2 & $0.0662(5)$ & $0.5691(4)$ & $0.1508(5)$ & $4.48(23)$ \\
C3 & $0.2456(4)$ & $0.4118(4)$ & $0.2059(4)$ & $4.79(24)$ \\
C4 & $0.3432(5)$ & $0.5934(4)$ & $0.3356(5)$ & $4.47(23)$ \\
C5 & $0.3042(4)$ & $0.5282(3)$ & $0.6511(4)$ & $3.35(17)$ \\
C6 & $0.3141(5)$ & $0.6313(3)$ & $0.8666(5)$ & $4.61(22)$ \\
C7 & $0.4422(6)$ & $0.7024(4)$ & $0.9537(6)$ & $6.1(3)$ \\
C8 & $0.5722(6)$ & $0.6425(5)$ & $1.0719(6)$ & $7.1(3)$ \\
C9 & $0.6108(5)$ & $0.5509(5)$ & $0.9999(5)$ & $6.0(3)$ \\
C10 & $0.4794(5)$ & $0.4821(4)$ & $0.9125(4)$ & $5.01(24)$ \\
N1 & $0.3575(3)$ & $0.5439(3)$ & $0.8004(3)$ & $4.04(17)$ \\
O1 & $-0.0567(4)$ & $0.3519(3)$ & $0.2647(4)$ & $6.33(21)$ \\
O2 & $-0.0154(4)$ & $0.6113(3)$ & $0.0397(3)$ & $6.93(21)$ \\
O3 & $0.2754(4)$ & $0.3594(3)$ & $0.1290(4)$ & $7.59(23)$ \\
O4 & $0.4314(3)$ & $0.649(3)$ & $0.3391(5)$ & $7.24(25)$ \\
\hline
\end{tabular}

Table 4

Selected bond distances $(\AA)$ and angles $\left(^{\circ}\right)$ for 2

\begin{tabular}{|c|c|c|c|}
\hline \multicolumn{4}{|l|}{ Bond lengths } \\
\hline $\mathrm{W}-\mathrm{S}$ & $2.6093(14)$ & $\mathrm{O}-\mathrm{C}(1)$ & $1.435(5)$ \\
\hline $\mathrm{W}-\mathrm{Sa}$ & $2.6093(14)$ & $\mathrm{C}(1)-\mathrm{C}(2)$ & $1.401(7)$ \\
\hline $\mathrm{W}-\mathrm{C}(3)$ & $2.009(4)$ & $\mathrm{C}(3)-\mathrm{O}(3)$ & $1.141(5)$ \\
\hline $\mathrm{W}-\mathrm{C}(3) \mathrm{a}$ & $2.009(4)$ & $\mathrm{C}(4)-\mathrm{O}(4)$ & $1.183(6)$ \\
\hline $\mathrm{W}-\mathrm{C}(4)$ & $1.910(5)$ & $\mathrm{S}-\mathrm{P}$ & $1.9859(17)$ \\
\hline $\mathrm{W}-\mathrm{C}(4) \mathrm{a}$ & $1.910(5)$ & $\mathrm{P}-\mathrm{Sa}$ & $1.9859(17)$ \\
\hline $\mathrm{P}-\mathrm{O}$ & $1.579(3)$ & $\mathrm{P}-\mathrm{Oa}$ & $1.579(3)$ \\
\hline \multicolumn{4}{|l|}{ Bond angles } \\
\hline $\mathrm{S}-\mathrm{W}-\mathrm{Sa}$ & $75.95(5)$ & $\mathrm{S}-\mathrm{P}-\mathrm{O}$ & 113.31(13) \\
\hline $\mathrm{S}-\mathrm{W}-\mathrm{C}(3)$ & $91.35(14)$ & $\mathrm{S}-\mathrm{P}-\mathrm{Oa}$ & $113.27(12)$ \\
\hline $\mathrm{S}-\mathrm{W}-\mathrm{C}(3) \mathrm{a}$ & $91.66(14)$ & $\mathrm{Sa}-\mathrm{P}-\mathrm{O}$ & $113.27(12)$ \\
\hline $\mathrm{S}-\mathrm{W}-\mathrm{C}(4)$ & $98.27(16)$ & $\mathrm{Sa}-\mathrm{P}-\mathrm{Oa}$ & $113.31(13)$ \\
\hline $\mathrm{S}-\mathrm{W}-\mathrm{C}(4) \mathrm{a}$ & $174.21(16)$ & $\mathrm{O}-\mathrm{P}-\mathrm{Oa}$ & $95.58(17)$ \\
\hline $\mathrm{Sa}-\mathrm{W}-\mathrm{C}(3)$ & $91.66(14)$ & $\mathrm{P}-\mathrm{O}-\mathrm{C}(1)$ & $120.6(3)$ \\
\hline $\mathrm{Sa}-\mathrm{W}-\mathrm{C}(3) \mathrm{a}$ & $91.35(14)$ & $\mathrm{O}-\mathrm{C}(1)-\mathrm{C}(2)$ & $111.9(4)$ \\
\hline $\mathrm{Sa}-\mathrm{W}-\mathrm{C}(4)$ & $174.21(16)$ & $\mathrm{W}-\mathrm{C}(3)-\mathrm{O}(3)$ & $176.8(4)$ \\
\hline $\mathrm{Sa}-\mathrm{W}-\mathrm{C}(4) \mathrm{a}$ & $98.27(16)$ & $\mathrm{W}-\mathrm{C}(4)-\mathrm{O}(4)$ & $178.7(4)$ \\
\hline$C(3)-W-C(3) a$ & $176.17(20)$ & $\mathrm{C}(3)-\mathrm{W}-\mathrm{C}(4)$ & $88.77(20)$ \\
\hline$C(3)-W-C(4) a$ & $88.47(19)$ & $\mathrm{C}(3) \mathrm{a}-\mathrm{W}-\mathrm{C}(4)$ & $88.47(19)$ \\
\hline $\mathrm{C}(3) \mathrm{a}-\mathrm{W}-\mathrm{C}(4) \mathrm{a}$ & $88.77(20)$ & $\mathrm{C}(4)-\mathrm{W}-\mathrm{C}(4) \mathrm{a}$ & $87.51(22)$ \\
\hline $\mathrm{W}-\mathrm{S}-\mathrm{P}$ & $88.07(6)$ & $\mathrm{S}-\mathrm{P}-\mathrm{Sa}$ & $107.90(10)$ \\
\hline
\end{tabular}

\subsection{X-ray crystallography}

\subsubsection{Single-crystal $X$-ray diffraction analyses of $\mathbf{1}$ and $\mathbf{2}$}

Single crystals of $\mathbf{1}$ and $\mathbf{2}$ suitable from X-ray diffraction analyses were grown by recrystallization from 20:1 $n$-hexane- $\mathrm{CH}_{2} \mathrm{Cl}_{2}$. The diffraction data were collected at r.t. on an Enraf-Nonius CAD4 diffractometer equipped with graphite-monochromated Mo $-\mathrm{K}_{\alpha}(\lambda=0.71073 \AA)$ radiation. The raw intensity data were converted to structure factor amplitudes and their esd's after correction for scan speed, background, Lorentz, and polarization effects. An empirical absorption correction, based on the azimuthal scan data, was applied to the data. Crystallographic computations were carried out on a Microvax III computer using the NRCC-SDP-VAX structure determination package [19].

Table 5

Atomic coordinates $\left(\times 10^{4}\right)$ and equivalent isotropic displacement coefficients $\left(\AA^{2} \times 10^{3}\right)$ for important atoms of $\mathbf{2}$

\begin{tabular}{|c|c|c|c|c|}
\hline Atom & $x$ & $y$ & $z$ & $B_{\text {eg }}$ \\
\hline W & 0 & $0.313843(18)$ & $1 / 4$ & $4.021(12)$ \\
\hline $\mathrm{S}$ & $0.08207(9)$ & $0.18704(8)$ & $0.15117(10)$ & $5.43(6)$ \\
\hline $\mathrm{P}$ & 0 & $0.11499(11)$ & $1 / 4$ & $4.80(9)$ \\
\hline $\mathrm{O}$ & $-0.06702(22)$ & $0.04959(17)$ & $0.1769(3)$ & $5.70(16)$ \\
\hline $\mathrm{Cl}$ & $-0.1466(4)$ & $0.0758(3)$ & $0.0924(5)$ & $7.5(3)$ \\
\hline $\mathrm{C} 2$ & $-0.1548(4)$ & $0.0236(3)$ & $-0.0056(5)$ & $8.9(4)$ \\
\hline $\mathrm{C} 3$ & $-0.1145(3)$ & $0.3180(3)$ & $0.1238(4)$ & $5.6(3)$ \\
\hline $\mathrm{O} 3$ & $-0.1788(3)$ & $0.3242(3)$ & $0.0518(3)$ & $9.61(24)$ \\
\hline $\mathrm{C} 4$ & $0.0681(4)$ & $0.3989(3)$ & $0.1694(4)$ & $6.3(3)$ \\
\hline $\mathrm{O} 4$ & $0.1096(3)$ & $0.45264(22)$ & $0.1209(4)$ & $10.0(3)$ \\
\hline
\end{tabular}


Table 6

Selected bond distances $(\AA)$ and angles $\left(^{\circ}\right)$ of Dithio-M(VIB)(0) complexes

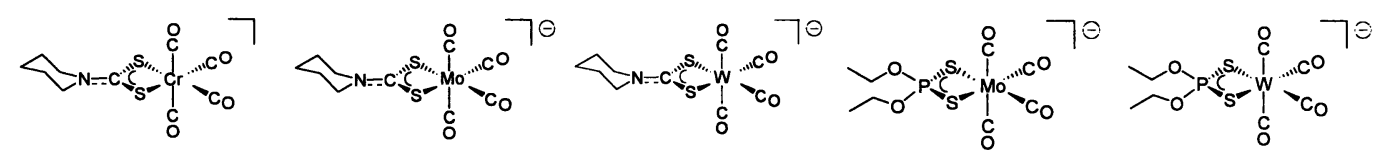

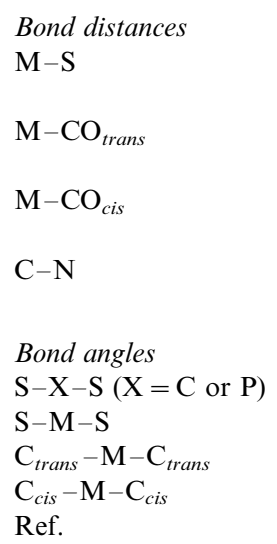

Bond distances

$\mathrm{M}-\mathrm{CO}_{\text {trans }}$

$\mathrm{M}-\mathrm{CO}_{\text {cis }}$

$\mathrm{C}-\mathrm{N}$

$$
\begin{aligned}
& 2.4766(13) \\
& 2.4679(12) \\
& 1.896(4) \\
& 1.856(4) \\
& 1.800(4) \\
& 1.836(4) \\
& 1.335(4)
\end{aligned}
$$

$$
\begin{aligned}
& 2.5898(16) \\
& 2.5978(13) \\
& 2.017(5) \\
& 2.033(5) \\
& 1.951(5) \\
& 1.930(5) \\
& 1.336(5)
\end{aligned}
$$

$2.6061(21)$
$2.5649(22)$
$1.993(8)$
$2.046(8)$
$1.984(9)$
$1.919(9)$
$1.335(9)$

$2.622(16)$

$2.023(4)$

$1.922(5)$

$2.6102(14)$

$2.012(6)$

$1.927(6)$

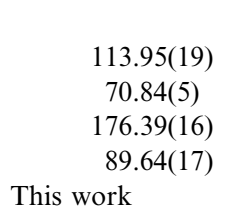

This work

$115.77(24)$
$67.91(4)$
$175.20(18)$
$89.74(20)$
This work

This work

$115.5(4)$
$67.83(6)$
$174.6(3)$
$89.5(4)$
$[15]$

$108.98(9)$
$75.87(5)$
$176.04(17)$
$87.06(19)$
$[8]$

$107.92(12)$

$76.07(7)$

$176.0(3)$

$87.5(4)$

This work

A suitable single crystal of $\mathbf{1}$ was mounted on the top of a glass fiber with glue. Initial lattice parameters were determined from 24 accurately centered reflections with $2 \theta \max 50.0^{\circ}$. Cell constants and other pertinent data were collected and are recorded in Table 1. Reflection data were collected using the $\theta / 2 \theta$ scan method. The final scan speed for each reflection was determined from the net intensity gathered during an initial prescan and ranged from 2.06 to $8.24^{\circ} \mathrm{min}^{-1}$. The $\theta$ scan angle was determined for each reflection according to the equation $0.65 \pm 0.35 \tan \theta$. Three check reflections were measured every $30 \mathrm{~min}$ throughout the data collection and showed no apparent decay. The merging of equivalent and duplicate reflections gave a total of 2110 unique measured data in which 1797 reflections with $I>2 \sigma(I)$ were considered observed. The structure was first solved by using the heavy-atom method (Patterson synthesis), which revealed the positions of metal atoms. The remaining atoms were found in a series of alternating difference Fourier maps and least-squares refinements. The quantity minimized by the least-squares program was $\omega\left(\left|F_{\mathrm{o}}\right|-\left|F_{\mathrm{c}}\right|\right)^{2}$, where $\omega$ is the weight of a given operation. The analytical forms of the scattering factor tables for the neutral atoms were used [20]. The nonhydrogen atoms were refined anisotropically. Hydrogen atoms were included in the structure factor calculations in their expected positions on the basis of idealized bonding geometry but were not refined in least squares. All hydrogens were assigned isotropic thermal parameters 1-2 $\AA^{2}$ larger then the equivalent $B_{\text {iso }}$ value of the atom to which they were bonded. The final residuals of this refinement were $R=0.027$ and $R_{\mathrm{w}}=0.028$.
Selected bond distances and angles and selected final atomic coordinates are listed in Tables 2 and 3.

The procedure for $\mathbf{2}$ was similar to those for $\mathbf{1}$. The final residuals of this refinement were $R=0.026$ and $R_{\mathrm{w}}=0.019$ for 2 . Selected bond distances and angles and selected final atomic coordinates are listed in Tables 4 and 5. Tables of thermal parameters are given in the supplementary material.

\section{Acknowledgements}

We thank the National Science Council of the Republic of China for support.

\section{References}

[1] (a) E. Lindner, H. Berke, J. Organomet. Chem. 39 (1972) 145; (b) D.J. Cole-Hamilton, T.A. Stephenson, J. Chem. Soc. Dalton Trans. (1974) 739;

(c) D.J. Cole-Hamilton, T.A. Stephenson, J. Chem. Soc. Dalton Trans. (1975) 754;

(d) D.J. Cole-Hamilton, T.A. Stephenson, J. Chem. Soc. Dalton Trans. (1978) 486;

(e) M.E. Nobel, J.C. Huffman, R.A.D. Wentworth, Inorg. Chem. 23 (1984) 631;

(f) J.H. Burk, G.E. Whitwell, II, J.T. Lemley, J.M. Burlitch, Inorg. Chem. 22 (1983) 1306;

(g) M.H. Chisholm, D.M. Ho, J.C. Huffman, W.G. Van Der Sluys, Polyhedron (1987) 1115;

(h) R.W. Hilts, M. Cowie, Inorg. Chem. 29 (1990) 3349.

[2] (a) A.W. Edelblut, R.A.D. Wentworth, Inorg. Chem. 19 (1980) 1110

(b) A.W. Edelbult, K. Folting, J.C. Huffman, R.A.D. Wentworth, J. Am. Chem. Soc. 103 (1981) 1927; 
(c) M.E. Noble, K. Folting, J.C. Huffman, R.A.D. Wentworth, Inorg. Chem. 23 (1984) 631;

(d) J.E. Pelati, J.C. Huffman, R.A.D. Wentworth, Inorg. Chem. 27 (1988) 2194.

[3] (a) J.W. McDonald, W.E. Newton, C.T.C. Creedy, J.L. Corbin, J. Organomet. Chem. 92 (1975) C25;

(b) R.S. Herrick, S.J. Burgmayer, J.L. Templeton, Inorg. Chem. 22 (1983) 3275;

(c) R.S. Herrick, J.L. Templeton, Organometallics 1 (1982) 842;

(d) J.R. Morrow, T.L. Tonker, J.L. Templeton, J. Am. Chem. Soc. 107 (1985) 5004;

(e) E.M. Armstrong, P.K. Baker, K.R. Flower, J. Chem. Soc. Dalton Trans. (1990) 2535.

[4] (a) M. Iglesias, C. Del Pino, S. Martnez-Carrera, Polyhedron 8 (1989) 484;

(b) S.G. Kukes, R.J. Hogan, D.M. Coombs, T. Davis, H.F. Efner, Eur. Pat. Appl. EP 160839, 1984; Chem. Abstr. 104 (1986) 53448z; (c) L.J. Velenyi, C. Paparizos, S.R. Dolhyj, US Patent 4262153, 1987; Chem. Abstr. 95 (1981) 80475h;

(d) W. Adam, R.M. Bargon, Chem. Commun. (2001) 1910.

[5] E.J. Steifel, Prog. Inorg. Chem. 22 (1977) 1.

[6] B. Zhuang, L. Huang, L. He, Y. Yang, J. Lu, Inorg. Chim. Acta 145 (1988) 225.

[7] (a) A.W. Edelbiut, K. Folting, J.C. Huffman, R.A.D. Wentworth, J. Am. Chem. Soc. 103 (1981) 1927;

(b) M.G.B. Drew, P.C.H. Mitchell, A.R. Read, J. Chem. Soc. Chem. Commun. (1982) 238;

(c) J.R. Dilworth, J. Chem. Soc. Dalton Trans. (1983) 397;

(d) M.G.B. Drew, R.J. Hobson, P.P.E.M. Mumba, D.A. Rice, N. Trup, J. Chem. Soc. Dalton Trans. (1987) 1163.

[8] K.H. Yih, G.H. Lee, Y. Wang, J. Organomet. Chem. 588 (1999) 125.

[9] W.D. Oliveira, J. Migot, M.B.G. Lima, J. Sala-Pala, J. Guerchais, J. Organomet. Chem. 248 (1985) 313.
[10] (a) G. Barrado, D. Miguel, J.A. Perea-Martinez, V. Riera, S. Garcia-Granda, J. Organomet. Chem. 466 (1993) 147;

(b) G. Barrado, D. Miguel, V. Riera, S. Garcia-Granda, J. Organomet. Chem. 489 (1995) 129;

(c) M.D. Curtis, O. Eisenstein, Organometallics 3 (1984) 887.

[11] (a) J.W. Faller, D.A. Haitko, R.D. Adams, D.F. Chodosh, J. Am. Chem. Soc. 101 (1979) 865;

(b) B.J. Brisdon, A.A. Woolf, J. Chem. Soc. Dalton Trans. (1978) 291.

[12] E.C. Alyea, A. Somogyvari, Inorg. Chem. Acta 83 (1984) L49.

[13] S. Woodward, U. Riaz, M.D. Curtis, Organometallic 9 (1990) 2703.

[14] (a) K.H. Yih, S.C. Yeh, Y.C. Lin, G.S. Lee, Y. Wang, Organometallics 17 (1998) 513;

(b) K.H. Yih, G.H. Lee, Y. Wang, Inorg. Chem. 39 (2000) 2445; (c) K.H. Yih, G.H. Lee, Y. Wang, Organometallics 20 (2001) 2604.

[15] K.H. Yih, Y.C. Lin, M.C. Cheng, Y. Wang, J. Organomet. Chem. 494 (1995) 149.

[16] Crystal data for $\left[\mathrm{Et}_{4} \mathrm{~N}\right]\left[\mathrm{Mo}\left(\mathrm{S}_{2} \mathrm{CNC}_{5} \mathrm{H}_{10}\right)(\mathrm{CO})_{4}\right]$ : $\mathrm{C}_{18} \mathrm{H}_{30} \mathrm{~N}_{2} \mathrm{O}_{4} \mathrm{~S}_{2} \mathrm{Mo}$, space group $P 2_{1}, a=9.993(2) \AA, b=12.710$ (3) $\AA, c=10.265(2) \AA, \beta=117.07(3)^{\circ}, V=1160.9(4) \AA^{3}, Z=2$, $D_{\text {calcd }}=1.426 \mathrm{~g} \mathrm{~cm}^{-3}, \mu=0.768 \mathrm{~mm}^{-1}$, independent reflections $2140, \theta_{\text {range }}=2.23-24.97^{\circ}$. Total number of parameters: $245 . R=$ $0.024, R_{w}=0.057$; GOF $=0.972, \mathrm{Mo}-\mathrm{K}_{\alpha}$ radiation; $\lambda=0.71073$ $\AA ; T=295(2) \mathrm{K} ; \Delta F=0.252,-0.201 \mathrm{e} \AA^{3}$.

[17] R. Eisenberg, Prog. Inorg. Chem. 112 (1970) 295.

[18] K.H. Yih, G.H. Lee, Y. Wang, Inorg. Chem. Commun. 3 (2000) 458.

[19] E.J. Gabe, F.L. Lee, Y. Lepage, in: G.M. Shhelldrick, C. Kruger, R. Goddard (Eds.), Crystallographic Computing 3, Clarendon Press, Oxford, 1985, p. 167.

[20] (a) International Tables for X-ray Crystallography vol. IV, Reidel, Dordrecht, 1974;

(b) Y. LePage, E. Gabe, J. Appl. Crystallogr. 23 (1990) 406. 